\title{
PENGARUH TERAPI RENDAM KAKI AIR HANGAT DITAMBAH GARAM TERHADAP TINGKAT STRES PEKERJA DI PT X
}

\author{
Wenny Nugrahati Carsita, Ade Riski Herlangga, Neneng Ratnanengsih Puspitasari \\ Sekolah Tinggi Ilmu Kesehatan (STIKes) Indramayu \\ wennynugraha16@gmail.com
}

\begin{abstract}
ABSTRAK
Kerja yang terlalu berat dapat mengakibatkan timbulnya stres. Stres kerja dapat berdampak negatif sehingga dapat mempengaruhi kinerja dan menurunnya prestasi. Stres kerja apabila tidak segera ditangani dapat juga berdampak pada penyakit fisik dan tekanan psikologis. Upaya untuk mengatasi stres salah satunya adalah dengan cara merendam kaki pada air hangat ditambah garam. Penelitian ini bertujuan untuk mengetahui pengaruh terapi rendam kaki air hangat di tambah garam terhadap tingkat stres pekerja di PT. X. Jenis penelitian ini adalah quasy experiment dengan metode pre test dan post test group design without control. Sampel penelitian berjumlah 30 orang dengan teknik pengambilan simple random sampling. Analisa data menggunakan uji Wilcoxon. Hasil penelitian sebelum diberikan intervensi yaitu sebanyak 12 responden $(40.0 \%)$ mengalami stres berat dan sesudah diberikan intervensi 11 respoden $(36.7 \%)$ tidak mengalami stres (normal). Hasil analisis didapatkan nilai $p$ value $0,000(\alpha<0,05)$ yang berarti terdapat pengaruh terapi rendam kaki ditambah garam terhadap tingkat stres pekerja. Diharapkan bagi perawat untuk mengedukasi kepada masyarakat tentang terapi rendam kaki air hangat sebagai salah satu alternatif untuk mengatasi stres dan dijadikan sebagai salah satu intervensi dalam menangani stres.
\end{abstract}

Kata kunci: Air Hangat Ditambah Garam, Pekerja, Terapi Rendam Kaki, Tingkat Stres

\section{ABSTRACT}

Work that is too heavy can cause stress. Work-related stress can have a negative impact so that it can affect performance and decrease performance. Work-related stress if not treated immediately can also have an impact on physical illness and psychological distress. Efforts to manage stress on of which can be done by soaking the feet in warm water added salt. The aim of this study was to determine the effect of therapy foot soak in warm water added salt against stress level of workers at PT. $X$. This study used a quantitative research design using quasi experiment with pre test dan post test group without control. Sampling technique used simple random sampling counted 30 people. Data analysis used Wilcoxon test. The results of the study before being given intervention were as many as 12 respondents (40.0\%) experienced severe stress and after being given intervention 11 respondents $(36.7 \%)$ did not experience stress (normal). analysis result showed p-value $=0,00(\alpha<$ $0,05)$, meaning there is any effect of therapy foot soak in warm water added salt against stress level of workers. It is hoped for nurses to educate the therapy foot soak in warm water added salt as an alternative to manage stress and serve as one of the interventions in dealing stress.

Keywords: Soak the feet of warm water added salt, Workers, Foot Soak Therapy, Stress Level 


\section{PENDAHULUAN}

Kerja merupakan kegiatan yang dapat mempengaruhi emosi dan proses berpikir seseorang (Handoko, 2008). Pekerjaan yang dianggap berat dan terlalu banyak dapat mengakibatkan timbulnya stres (Jum'ati \& Wuswa, 2013). Stres akibat pekerjaan diartikan sebagai reaksi atau respon seseorang terhadap situasi yang dianggap sebagai tuntutan atau tekanan yang tidak semestinya yang terjadi di tempat kerja (Bhui, et al., 2016).

Stres tidak selalu memberikan dampak negatif (distress), karena stress juga dapat berdampak positif (eustress) (Gadzella, et al., 2012). Stres dapat mendorong seseorang untuk bekerja lebih baik. Sebaliknya, stres juga dapat menurunkan kinerja seseorang sehingga akan berdampak pada menurunnya prestasi (Jum'ati \& Wuswa, 2013).

Di Inggris, pada tahun 2015 diketahui sebanyak 440.000 orang mengalami stres, depresi, serta kecemasan yang berhubungan dengan pekerjaan (Bhui et al., 2016). Hasil survei Regus pada lebih dari 16 ribu pekerja di seluruh dunia, ditemukan bahwa $64 \%$ pekerja Indonesia mengatakan mengalami peningkatan stress dibandingkan dengan tahun sebelumnya (Ramadian, 2012).

Stres dapat menyebabkan masalah fisik dan psikologis (Bhui, et al., 2016). Stres membuat seseorang rentan terhadap penyakit (Salleh, 2008). Diperkirakan 75\%-90\% pasien yang berkunjung ke dokter disebabkan oleh penyakit yang berhubungan dengan stress seperti sakit kepala, kelelahan, sakit maag, masalah jantung, sakit punggung, obesitas, diabetes, serta masalah tidur. Stress juga yang berlangsung lama juga dapat mengakibatkan penyakit kejiwaan (Salleh, 2008; Jackson, 2013).
Stres di tempat kerja akan membawa dampak pada perusahaan. Pekerja yang mengalami stres akan lebih rentan mengalami masalah kesehatan yang berakibat pada kecelakaan kerja. Pekerja juga tidak dapat bekerja secara produktif (Kurnia, 2015). Selain itu, stres juga dapat mengganggu pekerja dalam berinteraksi.

Potter dan Perry (2005) mengungkapkan stres dapat diatasi dengan humor dan diet. Jackson (2013) menambahkan stres juga dapat diatasi dengan olahraga. Rapoliene et al. (2016) menjelaskan terdapat beberapa upaya yang terbukti dalam mengatasi stres di antaranya pemulihan, tidur, relaksasi, meditasi, serta hidroterapi.

Hidroterapi merupakan terapi dengan menggunakan air dalam berbagai bentuk dan berbagai temperatur. Penggunaan air tersebut dapat menghasilkan efek yang berbeda pada sistem tubuh yang berbeda (Mooventhan, \& Nivethitha, 2014). Hidroterapi memberikan manfaat seperti meningkatkan energi, meningkatkan fungsi kulit dan penampilan, serta memperbaiki kesehatan (Chaitow, 2016).

Terapi rendam kaki air hangat ditambah garam dapat memberikan efek relaksasi bagi tubuh (Becker et al., 2009; Nuyridayanti, 2017). Ketenangan yang dirasakan pekerja akan berpengaruh pada kondisi psikologis serta perilaku yang dapat meningkatkan kinerja.

Hasil penelitian Darmasanti, dkk. (2018) diperoleh bahwa terapi rendam kaki dengan air hangat dapat menurunkan tingkat kecemasan pada ibu hamil trimester III. Berdasarkan studi pendahuluan melalui wawancara pada 10 pekerja didapatkan hasil 5 pekerja sering mengalami ketegangan otot, merasa jengkel dan 4 pekerja mengalami emosi 
yang tidak stabil, dan 1 pekerja mengalami kebingungan. Penelitian ini bertujuan untuk mengetahui pengaruh terapi rendam kaki air hangat ditambah garam terhadap tingkat stres pekerja di PT X.

\section{METODE PENELITIAN}

Jenis penelitian ini menggunakan desain quasy experiment menggunakan one grup pre test dan post design without control. Sampel dalam penelitian ini merupakan pekerja di PT. X dengan rentang usia 20-65 tahun sebanyak 30 responden. Teknik pengambilan sampel dilakukan secara acak (simple random sampling). Instrumen yang digunakan pada penelitian ini mengadopsi kuesioner DASS-21.
Peneliti mendatangi rumah setiap responden. Peneliti melakukan pre test terlebih dahulu dengan mengukur tingkat stres responden. Setelah dilakukan pre test peneliti melakukan terapi rendam kaki air dengan suhu $37,4^{\circ} \mathrm{C}$ ditambah garam laut sebanyak 3 sendok makan. Alat bantu yang digunakan meliputi Thermometer TP 3001, baskom karet, gayung plastik, dan handuk. Terapi dilakukan selama 10 menit $1 \mathrm{x} /$ hari selama 1 minggu berturut-turut. Post tes dilakukan pada hari ketujuh dengan mengukur kembali tingkat stres responden.

Selanjutnya peneliti melakukan pengolahan data dengan menggunakan langkah-langkah meliputi editing, coding, processing, dan tabulating. Analisa data menggunakan uji Wilcoxon dengan tingkat kemaknaan $\quad 95 \% \quad(\alpha=0,05)$.

\section{HASIL}

Karakteristik Responden

Tabel 1

Karakteristik Berdasarkan Umur

\begin{tabular}{ccccccc}
\hline & N & mean & median & sd & min-max & 95\% CI \\
\hline umur & 30 & 27.03 & 26.65 & 4.560 & $21-40$ & $\begin{array}{c}25.33- \\
28.74\end{array}$ \\
\hline
\end{tabular}

Berdasarkan tabel 1 didapatkan dengan umur tertua adalah 40 tahun dan rata-rata umur responden adalah 27 tahun umur termuda adalah 21 tahun.

Tabel 2

Karakteristik Berdasarkan Jenis Kelamin dan Tingkat Pendidikan

\begin{tabular}{lcc}
\hline $\begin{array}{c}\text { Karakteristik } \\
\text { responden }\end{array}$ & Frekuensi (F) & Persentase(\%) \\
\hline Jenis kelamin & 20 & 66.7 \\
Laki-laki & 10 & 33.3 \\
Perempuan & & \\
\hline Tingkat & & \\
pendidikan & 1 & 3.3 \\
DIII & 29 & 96.7 \\
SMA & &
\end{tabular}


Berdasarkan tabel 2 sebanyak 20 responden $(66.7 \%)$ berjenis kelamin lakilaki dan 10 responden berjenis kelamin perempuan $(33,3 \%)$. Sebanyak 29 responden $(96,7 \%)$ berpendidikan SMA dan 1 responden $(3,3 \%)$ berpendidikan DIII.

Analisis Univariat

Tabel 3

Tingkat Stress Sebelum dan Sesudah Terapi Rendam Kaki Air Hangat Ditambah Garam

\begin{tabular}{llllllll}
\hline & $\begin{array}{l}\text { Tingkat } \\
\text { stress }\end{array}$ & Normal & $\begin{array}{l}\text { Stress } \\
\text { ringan }\end{array}$ & $\begin{array}{l}\text { Stress } \\
\text { sedang }\end{array}$ & $\begin{array}{l}\text { Stress } \\
\text { berat }\end{array}$ & $\begin{array}{l}\text { Stress } \\
\text { sangat } \\
\text { berat }\end{array}$ & Total \\
\hline Sebelum & $\begin{array}{l}\text { Frekuensi } \\
\text { percentase }\end{array}$ & 0 & 8 & 10 & 12 & 0 & 30 \\
\hline Sesudah & $\begin{array}{l}\text { Frekuensi } \\
\text { percentase }\end{array}$ & 11 & $26.7 \%$ & $33.3 \%$ & $40.0 \%$ & $0 \%$ & $100 \%$ \\
\hline
\end{tabular}

Berdasarkan tabel 3 didapatkan sebelum dilakukan terapi rendam kaki air hangat ditambah garam sebanyak 8 $(26,7 \%)$ responden mengalami stress ringan, $10(33,3 \%)$ mengalami stress sedang, dan 12 (40,0\%) mengalami stress Analisis Bivariat

Tabel 4

Perbedaan Tingkat Stress sebelum dan sesudah Terapi Rendam Kaki Air Hangat Ditambah Garam

\begin{tabular}{ccccccc} 
& N & Sd & $\begin{array}{c}\text { Mea } \\
\mathbf{n}\end{array}$ & $\begin{array}{c}\text { Minimu } \\
\mathbf{m}\end{array}$ & $\begin{array}{c}\text { Maximu } \\
\mathbf{m}\end{array}$ & P \\
\hline $\begin{array}{c}\text { Tingkat stress sebelum } \\
\text { intervensi }\end{array}$ & 30 & $\begin{array}{c}3.03 \\
7\end{array}$ & 12.5 & 8 & 16 & 0.000 \\
$\begin{array}{c}\text { Tingkat stress sesudah } \\
\text { intervensi }\end{array}$ & 30 & $\begin{array}{c}2.37 \\
1\end{array}$ & 8.37 & 5 & 12 &
\end{tabular}

Berdasarkan tabel 4 didapatkan perbedaan nilai rata-rata tingkat stress sebanyak 4,13 sebelum dan sesudah dilakukan terapi rendam kaki air hangat

\section{PEMBAHASAN}

Hasil penelitian didapatkan sebelum diberikan terapi rendam kaki air hangat ditambah garam sebanyak 12 responden $(40.0 \%)$ mengalami stres berat berat. Setelah dilakukan terapi rendam kaki air hangat ditambah garam didapatkan $11(36,7 \%)$ responden tidak mengalami stress (normal), $11(36,7 \%)$ mengalami stress ringan, dan $8(26,7 \%)$ mengalami stress sedang.

ditambah garam dengan nilai $p$-value $=$ $0,000(\alpha=0,05)$ maka dapat disimpulkan terdapat pengaruh terapi rendam kaki ditambah garam terhadap tingkat stress.

dan sesudah dilakukan terapi rendam kaki air hangat didapatkan 11 responden (36.7\%) menjadi tidak mengalami stres (normal). 
Robbins dan Judge (2013) mengungkapkan stres kerja disebabkan oleh tiga faktor meliputi faktor lingkungan, organisasi, serta pribadi. Pada faktor lingkungan, ketadikpastian di lingkungan tempat bekerja akan mempengaruhi tingkat stress para pekerja. Kedua, faktor organisasi dapat menyebabkan stress seperti tuntutan untuk menyelesaikan pekerjaan, memiliki rekan kerja yang tidak menyenangkan, hubungan yang kurang baik dengan atasan. Ketiga adalah faktor pribadi yaitu pengalaman atau masalah yang dihadapi pekerja yang bersifat pribadi seperti masalah keluarga, ekonomi, karakteristik pekerja.

Stres dapat diatasi dengan cara farmakologi dan non farmakologi. Salah satu penanganan stres dengan cara non farmakologi adalah dengan hidroterapi dengan cara perendaman kaki pada air hangat ditambah garam. Hasil analisis perbedaan tingkat stress sebelum dan sesudah dilakukan terapi rendam kaki air hangat ditambah garam dengan menggunakan uji Wilcoxon didapatkan rata-rata 4,13 dengan nilai $p$-value $=$ $0,000(\alpha=0,05)$. Dari hasil tersebut dapat diketahui bahwa terdapat perbedaan tingkat stres sebelum dan sesudah dilakukan terapi rendam kaki air hangat ditambah garam.

Perendaman kaki dengan air hangat selama 10 menit telah terbukti menurunkan kekuatan saraf simpatik sehingga dapat menciptakan perasaan senang dan rileks. Pada orang dewasa, perendaman kaki menggunakan air hangat ditambah garam mampu menghasilkan perubahan fisiologis yang memberikan manfaat yang banyak bagi kesehatan (Becker, et al., 2009).

Terapi rendam kaki air hangat akan menyebabkan otot berelaksasi dan pembuluh darah melebar sehingga darah yang membawa oksigen akan cepat mencapai jaringan (Chaitow, 2016). Dengan melakukan terapi tersebut, hormon serotonin di dalam tubuh akan terstimulasi yang kemudian diubah menjadi melatonin yang dapat menimbulkan efek relaksasi (Lendengtariang et al., 2018). Turner dan Merriman (2005) menjelaskan rendam kaki dengan air hangat dapat merangsang sekresi hormone endorphin yang dapat memberikan rasa nyaman dan ketenangan.

Garam laut memiliki kandungan zat kimia seperti sodium dan natrium yang dapat mengatur keseimbangan cairan dalam tubuh juga bertugas dalam transmisi saraf dan kerja otot (Nuyridayanti, 2017). Penelitian lain yang dilakukan oleh Wulandari, dkk. (2016) diperoleh hasil bahwa pada penderita hipertensi mengalami penurunan tekanan darah setelah dilakukan rendam air hangat dengan campuran garam dan serai.

\section{SIMPULAN}

Sebelum diberikan intervensi sebanyak 12 responden (40.0\%) mengalami stres berat. Sesudah diberikan intervensi sebanyak 11 responden $(36.7 \%)$ tidak mengalami stres (normal). Dengan demikian dapat disimpulkan bahwa terdapat pengaruh terapi rendam kaki air hangat ditambah garam terhadap tingkat stres.

\section{SARAN}

\section{Bagi Responden}

Bagi para pekerja, terapi rendam kaki air hangat ditambah garam dapat dijadikan upaya untuk mengatasi stres. 


\section{Bagi Perawat}

Bagi perawat diharapkan dapat memberikan edukasi kepada masyarakat bahwa terapi rendam kaki air hangat ditambah garam merupakan salah satu upaya yang dapat dilakukan untuk mengatasi stres dan dapat dijadikan sebagai salah satu intervensi dalam melaksanakan asuhan keperawatan untuk mengatasi stres.

\section{DAFTAR PUSTAKA}

Bhui, K., Dinos, S., GalantMiecznikowska, M., De Jongh, B., \& Stansfeld, S. (2016). Perceptions of work stress causes and effective interventions in employees working in public, private and nongovernmental organisations: A qualitative study. BJPsych Bulletin, 40, 318-325. doi: 10.1192/pb.bp.115.050823.

Becker, B.E., Hildenbrand, K., Whitcomb, R.K., \& Sanders J.P. (2009). Biophysiologic Effects of Warm Water Immersion. International Journal of Aquatic Research and Education, 3, 24-3.

Chaitow, L. (2016). HYDROTHERAPY: Wather therapy for health and beauty. Australia: Pavilion book.

Darmasanti, P., Anggraini, R., \& Setianingsih. (2018). Pengaruh rendam kaki dengan air hangat terhadap tingkat kecemasan pada ibu hamil trimester III di Puskesmas Pegandon Kendal. Nurscope: Jurnal Keperawatan dan Pemikiran Ilmiah, 4 (1), 1-10.

Gadzella, B.M., Baloglu, M., Masten, W.G., \& Wan, Q. (2012). Evaluation of student life-stress inventory-revised. Jurnal of
Instructional Psychology, 39(2), 8291.

Handoko. T.H. (2008). Manajemen Personalia \& Sumber Daya Manusia Edisi 2. Yogyakarta: BPFE-Yogyakarta.

Jackson, E.M. (2013). Stress relief: The role of exercise stress management. ACSM's Health \& Fitness Journal, 17(3), 14-19. doi: 10.1249/FIT.0b013e31828cb1c9.

Jum'ati, N., \& Wuswa, H. 2013. Stress kerja (occupational stress) yang mempengaruhi kinerja individu pada Dinas Kesehatan bidang pencegahan pemberantasan penyakit dan penyehatan lingkungan (P2P-PL) di Kabupaten Bangkalan. Jurnal NeO-Bis, 7(2).

Kurnia, N.P. (2015). The Impact of stress at work on employee's psychological well-being in Jakarta. iBuss Management, 3(2), 68-76.

Lendengtariang, C., Wungouw, H., \& Hamel, R.S. (2018). Pengaruh terapi rendam air hangat kaki terhadap insomnia pada lansia di Kelurahan Angges Kecamatan Tahuna Barat. e-journal Keperawatan (e-Kp), 6(2), 1-8.

Mooventhan, A., \& Nivethitha, L. (2014). Scientific evidence-based effects of hydrotherapy on various systems of the body. North American Journal of Medical Sciences, 6(5), 199-209. doi: 10.4103/1947-2714.132935.

Nuyridayanti, A. (2017). Pengaruh rendam air garam terhadap penurunan tingkat nyeri pada penderita gout di desa Toyoresmi kecamatan Gampengrejo Kabupaten Kediri. Jurnal Kesehatan, 1(2), 116-121. 
Potter \& Perry. (2005). Buku Ajar Fundamental Keperawatan Edisi 4 Vol. 1. Jakarta: EGC.

Ramadian, G. (2012, September 17). Waspada, Stres Intai 64 Persen Pekerja di Indonesia. okezone.com: http://lifestyle.okezone.com/read/20 12/09/17/198/691019/waspadastres-intai-64-persen-pekerja-diindonesia.

Rapoliene, L., Razbadauskas, A., Salyga, J., \& Martinkenas, A. (2016). Stress and fatigue management using balneotherapy in a short-time randomized controlled trial. Evidence-based Complementary and Alternative Medicine. doi: 10.1155/2016/9631684.

Robbins, S.P., \& Judge T.A. (2013). Organizational Behavior $15^{\text {th }}$ Edition. Boston: Pearson Education. Salleh, M.R. (2008). Life event, stress and illness. The Malaysian Journal of Medical Science, 15(4), 9-18.
Turner, W., \& Merriman, L. (2005). Clinical Skills In Treating The Foot $2^{\text {nd }}$ Edition. China: Elsevier.

Wulandari, P., Arifianto, Sekarningrum, D. (2016). Pengaruh rendam kaki menggunakan menggunakan air hangat dengan campuran garam dan serai terhadap penurunan tekanan darah pada penderita hipertensi di wilayah Podorejo RW 08 Ngaliyan. Jurnal Keperawatan, 7(1), 43-47. 